\title{
Día Mundial de la Salud 2015: inocuidad de los alimentos
}

\author{
World Health Day 2015: food safety
}

\section{Christian Miranda-Orrillo}

Presidente de la Academia Peruana de Salud

Director general del Fondo Editorial Comunicacional

Este año la OMS ha designado al Día Mundial de la Salud 2015 como el de la inocuidad de los alimentos, y la primera reflexión que se nos viene a la mente es la epidemia del cólera de comienzos de la década de 1990. Las lecciones que nos dejó la epidemia del cólera en 1991 fueron, al igual que sus consecuencias, cuantiosas. El cólera, causado habitualmente por beber agua 0 comer alimentos contaminados, desnudó una población carente de educación y sentido crítico de higiene y normas elementales de alimentación segura y tratamiento de agua.

Una segunda reflexión es el número enorme de niños que han muerto por enfermedades diarreicas agudas, y no necesariamente relacionadas al cólera. En 1990, 79 de cada 1000 niños menores de cinco años morían en el Perú; hoy, en 2012, ese índice se redujo a 18 víctimas, cifra que no deberíamos aún aplaudir, cuando tan solo nuestro vecino del sur redujo la mortalidad infantil a cerca de 7 por 1000 niños menores de cinco años.

Si entendemos la inocuidad alimentaria como la garantía de que los alimentos no causarán daño al consumidor cuando se preparen y/o consuman de acuerdo con el uso a que se destinan, y que deberá de abarcar toda la cadena alimenticia, desde la producción al consumo. Un alimento se considera contaminado cuando contiene agentes vivos (virus 0 parásitos riesgosos para la salud), sustancias químicas tóxicas u orgánicas extrañas a su composición normal o componentes naturales tóxicos en concentración mayor a las permitidas.

Las enfermedades transmitidas por los alimentos suponen una importante carga para la salud. Millones de personas enferman en el mundo, y muchas mueren por consumir alimentos insalubres, sobre todo en países en vías de desarrollo.
Por ejemplo, la detección en el año 2000 de casos autóctonos de encefalopatía espongiforme bovina en el ganado de países europeos considerados hasta entonces libres de la enfermedad avivó la inquietud acerca de la extensión de la epidemia de encefalopatía bovina, y suscitó interrogaciones sobre los posibles riesgos para la salud pública. La inquietud traspasó las fronteras de Europa, en parte a causa de la incertidumbre sobre los riesgos posiblemente asociados a las importaciones anteriores a esa fecha de bovinos y productos derivados de bovinos procedentes de países afectados por la enfermedad.

El primer caso de encefalopatía bovina fue reportado en el Reino Unido, en 1986. La enfermedad en humanos, la variante de la enfermedad de CreutzfeldtJacob se asocia a la encefalopatía bovina y ha habido numerosos casos definitivos o probables a causa de la variante de Creutzfeldt-Jacob.

Perú, al igual que muchos países de América y del mundo, en su momento, reconoció la necesidad de controlar la producción de alimentos en todas sus etapas. Cuando las autoridades de salud se percataron de la ocurrencia de casos de enfermedades ligadas al consumo de alimentos presuntamente contaminados con agentes patógenos -fue el caso de la fiebre tifoidea y el consumo de verduras, aguas y refrescos contaminados; la teniasis, por consumo de carne de cerdos criados de forma insalubre, parasitados muchas veces con las larvas infectantes (cisticercos)estos venían haciendo estrago en la población hacía décadas.

Es por esto que la inocuidad de los alimentos es vital para evitar muertes innecesarias, controlables y recuperables, para una sociedad que debió invertir en salud, en prevención y sobre todo en educación. 